\title{
ERRATA
}

\section{Sampling Strategy for Detecting Viruses in a Sewage Treatment Plant}

\author{
D. ROLLAND, J. C. JORET, F. VILLEVAL, J. C. BLOCK, AND P. HARTEMANN \\ Laboratoire d'Hygiène et de Recherche en Santé Publique, Faculté de Médecine, 54505 Vandoervre Les \\ Nancy Cedex, France
}

Volume 45, no. 6, p. 1769, column 1, last line: “. . . October 1980.” should read “. . . April 1980."

Page 1770, Table 4, footnote $a$ : The minus sign in Table 4 is defined as follows: " $-=P<0.1$."

Page 1771, Table 5: The title of Table 5, "Correlation coefficients between parameters" should read "Correlation coefficients between raw wastewater parameters."

Page 1772, Table 8: The title of Table 8, "Correlation coefficients between parameters" should read "Correlation coefficients between treated wastewater parameters."

Page 1773, Table 10, column 6, line 9: "91.07" should read "91.1."

Page 1773, Table 10, column 6, line 10: "97.63" should read "97.6."

Page 1774, column 1, reference 3: "Eau" should read "Tech. Sci. Munic. Eau."

\section{Fermentative Degradation of Polyethylene Glycol by a Strictly Anaerobic, Gram-Negative, Nonsporeforming Bacterium, Pelobacter venetianus sp. nov. BERNHARD SCHINK AND MARION STIEB \\ Fakultät für Biologie, Universität Konstanz, D-7750 Konstanz, West Germany}

Volume 45, no. 6, p. 1913, column 2: The following reference should be added to the Literature Cited:

36a. Stephanou, E., and W. Giger. 1982. Persistent organic chemicals in sewage effluent. II. Quantitative determinations of nonylphenols and nonylphenol ethoxylates by glass capillary gas chromatography. Environ. Sci. Technol. 16:800-805.

\section{Production and Characteristics of Raw Starch-Digesting Glucoamylase $\mathrm{O}$ from a Protease-Negative, Glycosidase- Negative Aspergillus awamori var. kawachi Mutant} PERFECTO Q. FLOR AND SHINSAKU HAYASHIDA

\section{Laboratory of Applied Microbiology, Department of Agricultural Chemistry, Kyushu University 46, Fukuoka} 812, Japan

Volume 45, no. 3, p. 906, column 2, lines 18 and 19: “(i) Step 1. Ammonium sulfate filtrate $(4,000$ $\mathrm{ml}$ ) was added to a portion of the culture filtrate to $60 \%$..." should read "(i) Step 1. Ammonium sulfate was added to a portion of the culture filtrate $(4,000 \mathrm{ml})$ to $60 \%$. . ." 